\title{
Teacher's Perception of the Utilization of Character- Themed Songs in PAUD Teaching and Learning Process in the Postmodern
}

\author{
Yunike Juniarti Fitria ${ }^{1, *}$, Herwin Yogo Wicaksono ${ }^{1, * *}$, Agustianto $^{1, * * *}$ \\ ${ }^{1}$ Department of Music Education, Yogyakarta State University, Depok 55281, Yogyakarta, Indonesia \\ *Corresponding author.Email: yunike_jf@uny.ac.id \\ ${ }^{* *}$ Corresponding author.Email: herwin_yw@uny.ac.id \\ ${ }^{* * *}$ Corresponding author. Email: agustianto@uny.ac.id
}

\begin{abstract}
This article aims to reveal the teacher's perception of the use of character-themed children's songs in PAUD schools in Yogyakarta, especially in the Sleman Regency, in the postmodern era. This research uses quantitative methods, with the type of survey research. The sample in this study were teachers and principals in PAUD schools with accreditation A in Sleman Regency, Yogyakarta. We select the sample using purposive sampling. Data collected through questionnaires and interviews. The validity of the instruments used is content validity and construct validity, and the analysis method of the data used in this research is descriptive analysis. We conducted this research in PAUD schools in the Sleman Regency, Yogyakarta, from March to July 2019. The reason for choosing the topic of the use of children's songs in PAUD schools is the importance of inculcation of character in the postmodern era. Early childhood is in a crucial phase to instill and shape the character of children. Also, music is very suitable as a learning media for early childhood. In addition to being a media for instilling positive values, children can develop themselves according to their abilities and interests through music. That way, children will become more honest with themselves and the surrounding environment, with direction from teachers and parents. According to postmodern teaching principles, the best teaching is an environment that can direct and support the various needs of each child.
\end{abstract}

Keywords: children's songs, character, PAUD, postmodern education

\section{EARLY CHILDHOOD EDUCATION IN THE POSTMODERN ERA}

Globalization has arrived at a new era called the fourth Industrial Revolution. The world has gone through three stages of the revolution, since the Industry 1.0 through the invention of the steam engine, followed by the Industry 2.0 by optimizing the use of electricity, and the third industrial revolution with the start of the computerized system [1]. After experiencing the previous three stages, it is now ingoing the era of the Industry 4.0 as marked by the presence of the Internet of Things (IoT) as a vital thing [2], and fundamentally resulting in changes in the way of life and ways of thinking of humans.

Jean Baudrillard argues, that today's society is no longer dominated by production, but rather the media, cybernetics, and industry [3]. Along with the development of the fourth industrial revolution, the era of the postmodern way of thinking arrives at the joints of human life at large. Postmodernism has developed since decades ago, however, the definition of the term "postmodernism" is still controversial and unclear to some people [4]. JeanFrancois Lyotard was possibly one of the people introducing postmodernism in the fields of philosophy and science in the 1970s [5]. In his book "The Postmodern Condition: A Report on Knowledge" he explains, postmodernism as all criticism of universal knowledge, foundationalism, and on modernism [6].

According to Setiawan \& Sudrajat, postmodernism is the anti-thesis of modernism as it deconstructs the modern paradigm. The development of modernism was marked by rationalism, materialism, religious moral disorientation and the collapse of human dignity [7]. Modernism holds the view that the truth of science must be objectively absolute, and the absence of human values. As for postmodernism, science is not objective but subjective and the interpretation of humans themselves, so the truth is relative [8]. Postmodernism was born from a critical attitude to modern thought, with the hope to restore views to respect humans as individuals who differ from one another. 
In such situation and view, education has its tasks and roles that are anticipatory, preventive, and rehabilitative towards problems arising in the context of the development of sophisticated science and technology, for example individualistic, hedonistic, consumeristic, permissive (completely permissible) and even chauvinistic (justifies any means to achieve goals) cultural patterns [9]. Education is meant especially in education at an early age. Throughout life, humans experience several phases of education. However, the level of education at an early age should receive more attention than other levels.

Childhood education that is being strongly promoted after family education is schools, namely early childhood education. At this level of education, many parents entrust their sons and daughters to receive their first formal education with the hope that their children get a good provision, especially in terms of social, discipline, and spirituality. Because in the whole process of education, early childhood education becomes the foundation for children to enter the primary education [10], and to then continue to the higher levels. This makes early childhood education schools (PAUD) have a very strategic role in shaping one's character.

\section{SONGS AS A MEDIA FOR BUILDING CHILDREN'S CHARACTER}

Children as potential future generations act as keys that determine the continuity of an era. Children are the main investment which is very central in facing global competition. In the future, human resources who will determine the continuity of time are the young generation. Therefore, it is important to prepare future generations as well as possible by instilling character education as early as possible.

Character is a basic human nature that is inherent and visible in every action and behaviour. In order that the character formed in everyone is the good one, character education needs to be taught to children from an early age and it can be done through education, education in both the family, school, and community. As Ki Hajar Dewantara said [11], in the process of child growth and development, character development can be promoted through the three pillars of education, namely education at home, at school, and in the community. These three pillars of education need to be integrated with one another to complement each other as all of them greatly influence the formation of children's behaviour, character, and personality.

Besides, character education will be more successful if it started in early childhood. This is because childhood is a crucial phase in which the formation of personality when children do not have a mature personality, in addition to the golden age when the human brain can be used optimally to absorb various information. At this very young age, children must have experienced character education in their family and at this stage, not much influx of influence from the surrounding environment bother them from growing their best character values.
The current era has been dominated by technology, and connection with the outside world has been very open. As said by Fitria \& Floriasti [12], currently, the younger generations are more individual because of their busy lives in cyberspace, so that they tend to be apathetic towards the surrounding environment. The thing contributing to this strong influence is possibly the mass media. It cannot be denied that the mass media bombards every line of human life, through television, print media, films, and various sites on the internet all of which later can influence the formation of children's character. Thus, it needs to be realized that one of the most urgent alternatives to be established and improved is the media that can balance the mass media and technology in shaping the character of children.

The projected media are songs associated with character development that are suitable for early aged children. Because music is one of the tools that can be used to shape and develop children's character. Music can shape characters through establishing and infusing beautiful or sensitive feelings. Softness or sensitivity of feelings as a result of absorbing beautiful feelings is an appropriate introduction in shaping a person's character and personality [13]. One of the inculcations of character values that can be done in PAUD is through songs which can be played in the school environment so that children can listen passively, and those taught by teachers and actively studied by children.

Based on the study conducted in one PAUD in Yogyakarta Special Province in January 2018 through an interview with one of the teachers, it was said that instilling character values in children can be carried out through songs that are appropriate to their age. This is also done in some PAUDs in Sleman Regency, Yogyakarta Special Province. Thus, this study seeks to express the perception of PAUD teachers in Sleman Regency Yogyakarta in relation to the use of character-themed songs in teaching and learning in schools.

\section{METHOD}

This study adopted a survey research model with quantitative methods. The questionnaire was used to obtain a collection of information about the population related to the use of character-themed songs in the PAUD teaching and learning process in Sleman Regency, a location used as a research sample. This means that data in the form of figures and opinions were gathered from the population by examining the population sample, and the questionnaire results as the primary data collection instrument will be described quantitatively [14]. The same thing was expressed by Sukmadinata [15], that survey research is used to collect data or information about large populations using relatively small samples [2008]. "Survey models are the research approaches that aim to define past or existing situations [16]". Thus, it can be said that survey research is used to examine cases that want to be explained precisely, in the present and past situations, by using a questionnaire for obtaining the required information. 


\subsection{Participants}

This study involved teachers and PAUD principals in Sleman Regency, Yogyakarta. The population in this study were all PAUDs situated in Sleman Regency. Meanwhile, the sample was PAUDs accredited "A" in 2018 in that area. This was obtained based on Suharsimi's opinion [17] stating if the population is less than 100 , it is better to take all so that the research becomes population research. If the population is large, then the sample taken can be between $10-15 \%$ or $20-55 \%$. In this context, the sampling technique employed was purposive sampling. This technique is used because of certain considerations, and the sample was intentionally selected [18].

Concerning this, PAUDs accredited " $A$ " in Sleman Regency in 2008-2018 were 144 in total. However, the sample taken for this study were those accredited " $A$ " in the year of 2018, covering 24 schools. In the sample, 48 participants contributing to this study include 1 teacher and 1 principal from each sample PAUD.

\subsection{Data Collection and Analysis}

In survey research, there are four data collection techniques [19] namely (1) a self-composed questionnaire; (2) interview; (3) review of structured notes; and (4) structured observation. Related to this research, the data collection instrument used was a questionnaire. The questionnaire contained statements related to indicators of the use of character-themed songs in the PAUD teaching and learning process in Sleman Regency, Yogyakarta, with a Likert scale in the alternative responses.

Likert scale can be used in the questionnaire focusing on the attitudes, opinions, and perceptions of a person or group of people about social phenomena [20]. With a Likert scale, the measured variables are translated into indicators, and these indicators serve as starting points for generate instrument items in the form of questions and statements.

Indicators in Point 3, concerning character-themed songs used in the PAUD teaching-learning process in the researched regency are derived from values stated in the character education as promoted by the ministry of national education of the Republic of Indonesia. They include being religious, honest, tolerant, disciplined, hardworking, creative, independent, democratic, curious, nationalistic, patriotic, appreciative, communicative, peace-loving, keen on reading, environmentally savvy, socially caring, and responsible.
Of these 18 character-values, 5 of them have been excluded in the research indicators, namely hardworking, democratic, nationalistic, patriotic, and appreciative. Though all of these values are worthwhile to instill at the early age of students' life, they are abstract things which might be difficult to process if seen from the psychological and cognitive development of the PAUD students. Thus, the blueprint of the instrument used in the research cover the following variables as seen in Table 1 .

Table 1. Research Instrument Grids

\begin{tabular}{|c|c|c|c|}
\hline Variable & Indicator & $\begin{array}{c}\text { Item } \\
\text { no. }\end{array}$ & $\begin{array}{c}\text { Source of } \\
\text { Data }\end{array}$ \\
\hline $\begin{array}{l}\text { The } \\
\text { frequency of } \\
\text { using songs } \\
\text { in the } \\
\text { teaching- } \\
\text { learning } \\
\text { process of } \\
\text { PAUD in } \\
\text { Sleman } \\
\text { Regency, } \\
\text { Yogyakarta }\end{array}$ & $\begin{array}{l}\text { a. Never } \\
\text { b. Seldom } \\
\text { c. Sometimes } \\
\text { d. Often }\end{array}$ & $\begin{array}{l}1,6 \\
12\end{array}$ & $\begin{array}{l}\text { PAUD } \\
\text { teachers } \\
\text { and } \\
\text { principals }\end{array}$ \\
\hline $\begin{array}{l}\text { The effect of } \\
\text { using songs } \\
\text { in the } \\
\text { teaching- } \\
\text { learning } \\
\text { process of } \\
\text { PAUD in } \\
\text { Sleman } \\
\text { Regency, } \\
\text { Yogyakarta }\end{array}$ & $\begin{array}{l}\text { a. Having good or bad } \\
\text { effects } \\
\text { b. Having no effect }\end{array}$ & $\begin{array}{l}4,9 \\
11 \\
13 \\
19\end{array}$ & $\begin{array}{l}\text { PAUD } \\
\text { teachers } \\
\text { and } \\
\text { principals }\end{array}$ \\
\hline \multirow{13}{*}{$\begin{array}{l}\text { The use of } \\
\text { character- } \\
\text { themed songs } \\
\text { in the } \\
\text { teaching- } \\
\text { learning } \\
\text { process of } \\
\text { PAUD in } \\
\text { Sleman } \\
\text { Regency, } \\
\text { Yogyakarta }\end{array}$} & a. Religiosity & 2,15 & \multirow{13}{*}{$\begin{array}{l}\text { PAUD } \\
\text { teachers } \\
\text { and } \\
\text { principals }\end{array}$} \\
\hline & b. Honesty & 5 & \\
\hline & c. Tolerance & 23 & \\
\hline & d. Discipline & 3 & \\
\hline & e. Creativity & 16 & \\
\hline & f. Independence & 8,22 & \\
\hline & g. Curiosity & $\begin{array}{l}11, \\
19\end{array}$ & \\
\hline & $\begin{array}{l}\text { h. Friendliness/ } \\
\text { i. Communicativeness }\end{array}$ & $\begin{array}{l}14, \\
24\end{array}$ & \\
\hline & j. $\quad$ Peace-loving & 14 & \\
\hline & k. Being Keen in Reading & 17 & \\
\hline & 1. Environmental savvy & 7,18 & \\
\hline & m. Social Caring & $\begin{array}{l}16, \\
18, \\
24, \\
25\end{array}$ & \\
\hline & n. Responsibility & 10 & \\
\hline
\end{tabular}


The data were later analysed descriptively in terms of their central size, spread, and trends. The central size itself consists of mean, median, and mode. This central measure is used to describe the state of the sample group observed [21]. This research describes and identifies teacher perceptions of the use of character-themed songs in the PAUD teaching and learning process in Sleman Regency.

\section{FINDINGS AND DISCUSSIONS}

The main objective of the study conducted is to provide an overview of teachers' perceptions of how songs are used in PAUD schools in Sleman, Yogyakarta. Henceforth, exploring the implementation of learning in PAUD in which songs were used as a learning media to instill good character in early childhood was done. Of the twenty-five statements in the questionnaire consisting of three categories, the first category is about how often songs are used in the learning process, the second is whether the played and taught songs with character influence children or not, and the third is related to items of character values. From the statements in the questionnaire, teachers and principals were asked to give firm answers, between Agree or Disagree. The results of the questionnaire, the percentage of agreed answers, can be seen in Chart 1 .

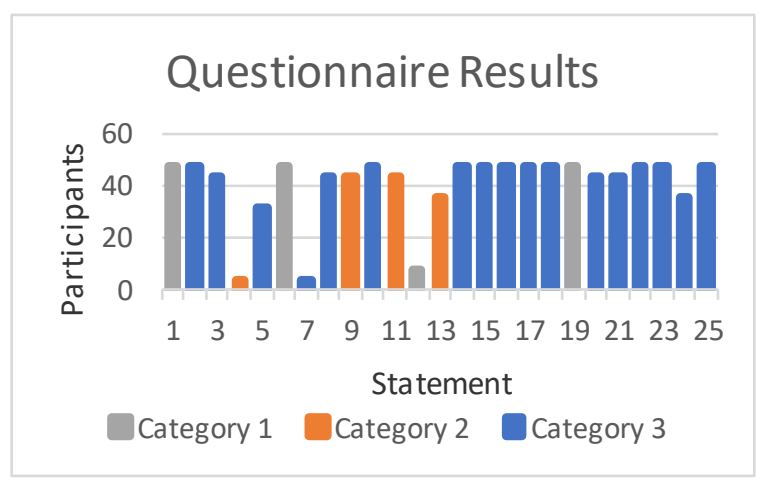

Chart 1 The Questionnaire Results, Those Who Responded "Agree" in

In Chart 1, the responses are described in each category. The first category is the statement about the frequent use of songs in the PAUD teaching and learning process in Sleman Regency Yogyakarta, as described in detail in Chart 2.

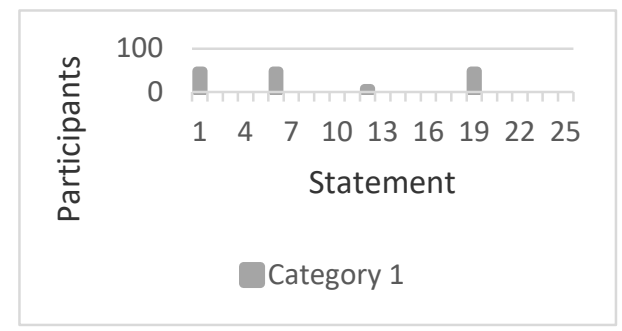

Chart 2 Questionnaire Results, “Agree" Responses from 4 Statements in Category 1

In statement No. 1, 6 and 19, teachers and school principals were asked to respond to whether in the learning process students were often played songs repeatedly. From these three statements, 48 respondents, teachers, and school principals agreed with the notion. The detailed data can be seen in Table 2 .

Table 2. The response percentage and frequency of statement no. 1,6 , and 19

\begin{tabular}{|l|r|r|r|r|}
\cline { 2 - 5 } \multicolumn{1}{c|}{} & $\begin{array}{c}\text { Freq } \\
\text { • }\end{array}$ & $\begin{array}{c}\text { Percentag } \\
\mathbf{e}\end{array}$ & $\begin{array}{c}\text { Valid } \\
\%\end{array}$ & $\begin{array}{c}\text { Cumulative } \\
\%\end{array}$ \\
\hline $\begin{array}{l}\text { Valid } \\
\text { Agre } \\
\text { e }\end{array}$ & 48 & 100.0 & 100.0 & 100.0 \\
\hline
\end{tabular}

All (100\%) of the respondents responded "Agree", that students often and repeatedly played a song. Aside from positive statements, there are negative ones in the questionnaire. For example, statement No. 12, as follows: When a song is played it interferes with the learning process, and therefore children rarely or never play a song. For this item, the responses can be seen in Table 3.

Table 3. The response percentage and frequency of statement no. 12

\begin{tabular}{|l|r|r|r|r|}
\cline { 2 - 5 } \multicolumn{1}{c|}{} & \multicolumn{1}{l|}{\begin{tabular}{l} 
Freq \\
\multicolumn{1}{c|}{}
\end{tabular}} & $\begin{array}{l}\text { Percenta } \\
\text { ge }\end{array}$ & $\begin{array}{l}\text { Valid } \\
\%\end{array}$ & \multicolumn{2}{l|}{$\begin{array}{l}\text { Cumulative } \\
\%\end{array}$} \\
\hline Disagre & 40 & 83.3 & 83.3 & 83.3 \\
e & 8 & 16.7 & 16.7 & 16.7 \\
Valid & 48 & 100.0 & 100.0 & 100.0 \\
Agree & & & & \\
Total & & & & \\
\hline
\end{tabular}

There were 8 respondents who stated that playing a song could interfere with the learning process. However, 40 other respondents did not agree that playing a song can interfere with student learning. In the interviews, several respondents stated that the songs played were in accordance with the materials being studied by students, in order to support, not otherwise interfere with, the learning process of students at schools. 
The second category of statements was to find out whether the use of songs in learning has an impact on students, whether good or bad, directly or indirectly. In relation to this, there are four statements in this category.

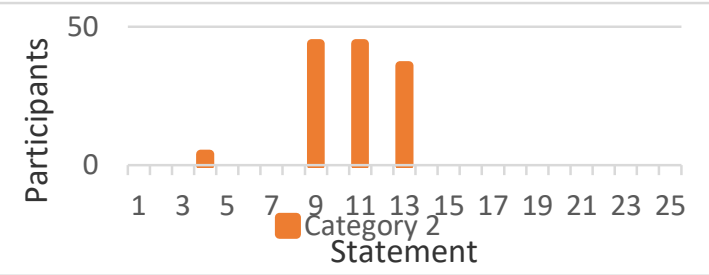

Chart 3 Questionnaire results, “Agree” Responses from 4 Statements in Category 2

In statement No. 4, namely "Songs that are played do not have any impact on children", only $8.3 \%$ or 4 people agreed, and the remaining $91.7 \%$ disagreed with the statement.

Table 4. The response percentage and frequency of statement no. 4

\begin{tabular}{|l|r|r|r|r|}
\cline { 2 - 5 } \multicolumn{1}{c|}{} & \multicolumn{1}{c|}{\begin{tabular}{c} 
Freq \\
\multicolumn{1}{c|}{}
\end{tabular}} & \multicolumn{1}{c|}{$\begin{array}{c}\text { Percenta } \\
\text { ge }\end{array}$} & \multicolumn{1}{c|}{$\begin{array}{c}\text { Valid } \\
\%\end{array}$} & \multicolumn{1}{c|}{$\begin{array}{c}\text { Cumulative } \\
\%\end{array}$} \\
\hline Disagre & 44 & 91.7 & 91.7 & 91.7 \\
e & 4 & 8.3 & 8.3 & 8.3 \\
Valid & 48 & 100.0 & 100.0 & 100.0 \\
Agree & & & \\
Total & & & & \\
\hline
\end{tabular}

From the statement in item No. 4 in Table 4, it can be determined that respondents agreed that playing music gives an effect on children.

Whereas in the statements No. 9 and 11, that playing a song has a good and very big effect on children's learning enthusiasm, there were $91.7 \%$ of respondents who agreed, as presented in the following table.

Table 5. The response percentage and frequency of statement no. 9

\begin{tabular}{|l|r|r|r|r|}
\cline { 2 - 5 } \multicolumn{1}{c|}{} & \multicolumn{1}{c|}{\begin{tabular}{c} 
Freq \\
\multicolumn{1}{c|}{}
\end{tabular}} & \multicolumn{1}{c|}{$\begin{array}{c}\text { Percenta } \\
\text { ge }\end{array}$} & \multicolumn{1}{c|}{$\begin{array}{c}\text { Valid } \\
\%\end{array}$} & $\begin{array}{r}\text { Cumulative } \\
\%\end{array}$ \\
\hline Disagre & 4 & 8.3 & 8.3 & 8.3 \\
e & 44 & 91.7 & 91.7 & 91.7 \\
Valid & 48 & 100.0 & 100.0 & 100.0 \\
Agree & & & & \\
Total & & & & \\
\hline
\end{tabular}

However, for item No.13, that song directly affects the behaviour of children, only $75 \%$ of respondents stated Agree as can be seen in Table 6 .
Table 6. The response percentage and frequency of statement no. 13

\begin{tabular}{|l|r|r|r|r|}
\cline { 2 - 5 } \multicolumn{1}{c|}{} & \multicolumn{1}{c|}{\begin{tabular}{c} 
Freq \\
\multicolumn{1}{c|}{}
\end{tabular}} & \multicolumn{1}{c|}{$\begin{array}{c}\text { Percenta } \\
\text { ge }\end{array}$} & \multicolumn{1}{c|}{$\begin{array}{c}\text { Valid } \\
\%\end{array}$} & $\begin{array}{c}\text { Cumulative } \\
\%\end{array}$ \\
\hline Disagre & 12 & 25.0 & 25.0 & 25.0 \\
e & 36 & 75.0 & 75.0 & 75.0 \\
Valid & 48 & 100.0 & 100.0 & 100.0 \\
Agree & & & \\
Total & & & & \\
\hline
\end{tabular}

The conclusion from Category 2 is about the use of songs in the learning process that gives a good effect on children. However, it was found that songs do not directly affect the child's behaviour. Some respondents noted that behaviour is not something that can be formed, changed, and can be seen as an instant change as changes in behaviour take a long time.

Category 2 statements are related to teachers' and principals' perceptions about the formation of character values instilled early on, and character values chosen according to the children's age. Respondents' responses can be seen in Chart 4 below.

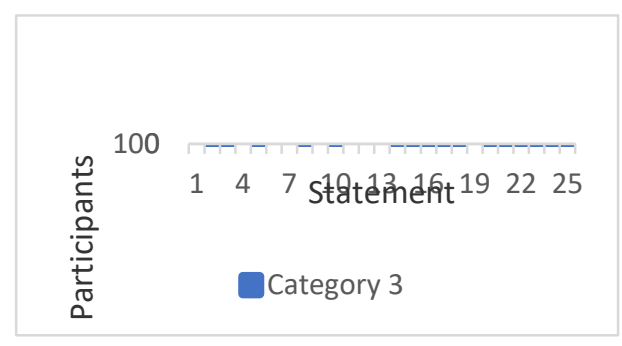

Chart 4 Questionnaire Results, “Agree" Responses from 17 statements in Category 3

There are several groups of responses in Category 3, and based on the percentage of responses, the first group is the statements that received $100 \%$ Agree, namely statement No. 2 and 15 (statements about the religious character values), 23 (tolerance), 16 (creativity and social care), 22 (independence), 19 (curiosity), 14 (friendliness and peace-loving), 17 (being keen of reading), and 18 (environment and social care) as can be seen on Chart 5 . 


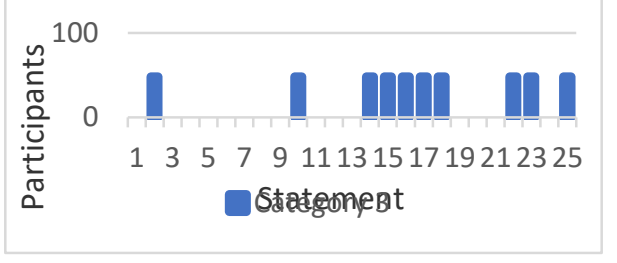

Chart 5 Statements from Category 3 with Agree responses as much as $100 \%$

The example statement No. 2 is given in Table 7 as follows.

Table 7. The response percentage and frequency of statement no. 2

\begin{tabular}{|l|r|r|r|r|}
\cline { 2 - 5 } \multicolumn{1}{c|}{} & \begin{tabular}{c} 
Freq \\
\multicolumn{1}{c|}{}
\end{tabular} & $\begin{array}{c}\text { Percentag } \\
\text { e }\end{array}$ & $\begin{array}{c}\text { Valid } \\
\%\end{array}$ & $\begin{array}{c}\text { Cumulative } \\
\%\end{array}$ \\
\hline $\begin{array}{l}\text { Valid } \\
\text { Agre } \\
\text { e }\end{array}$ & 48 & 100.0 & 100.0 & 100.0 \\
\hline
\end{tabular}

It is apparent from the table that 48 respondents agreed to the statement that the values of religiosity, tolerance, creative and social care, independence, curiosity, friendship and love for peace, love to read and care for the environment, and social care can be more easily instilled in children in the early age through songs as a learning media.

The second group from Category 3 is the statements that received the agreement, as much as $91.7 \%$, as presented in Chart 6.

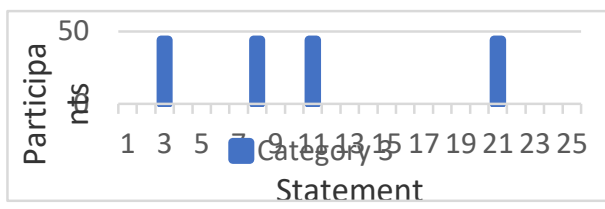

Chart 6 Statements from Category 3 with "Agree" Responses as Much as $91.7 \%$

A total of 44 respondents agreed that songs can be used to teach the values of discipline, independence, and curiosity (contained in statements No. 3, 8, and 11), and statement No. 21 which states the importance of explaining the meaning of the theme contained in the song every time children were invited to sing. Examples of data in Statement 3 are presented as follows.
Table 8. The response percentage and frequency of statement no. 3

\begin{tabular}{|l|r|r|r|r|}
\cline { 2 - 5 } \multicolumn{1}{c|}{} & \multicolumn{1}{c|}{\begin{tabular}{c} 
Freq \\
\multicolumn{1}{c|}{}
\end{tabular}} & \multicolumn{1}{c|}{$\begin{array}{c}\text { Percenta } \\
\text { ge }\end{array}$} & \multicolumn{1}{c|}{$\begin{array}{c}\text { Valid } \\
\%\end{array}$} & \multicolumn{1}{c|}{$\begin{array}{c}\text { Cumulative } \\
\%\end{array}$} \\
\hline Disagre & & 8.3 & 8.3 & 8.3 \\
e & 4 & 91.7 & 91.7 & 91.7 \\
Valid & 44 & 100.0 & 100.0 & 100.0 \\
Agree & 48 & & & \\
Total & & & \\
\hline
\end{tabular}

Then from Category 3, there are three statements with different percentages. They can be observed in Chart 7 .

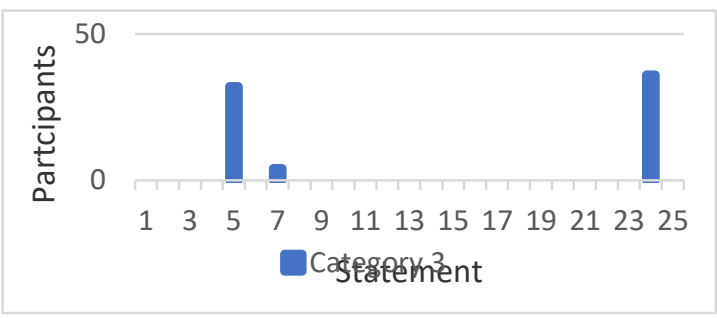

Chart 7 Statements in Category 3 with "Agree" Responses of $75 \%, 66.7 \%$, and $8.3 \%$

In item No. 24, the "Agree" responses are as much as $75 \%$, stating that children's songs significantly change the behaviour patterns of the children in the courage to communicate with friends. Item No. 5 shows that $66.7 \%$ of respondents agreed that children have an honest attitude after singing a song.

Furthermore, $8.3 \%$ of respondents agreed with the statement in No. 7 that even though the song has been sung by children, they do not care about the environment, or it can be read that $91.7 \%$ of 44 respondents agreed that playing a song can change children's concern for the environment.

The conclusion of this group of answers is that by playing and being taught the value of characters through songs, children can change and increase the courage of communication and cause a sense of concern for the environment. However, approval of statements related to changes in honesty received only a small percentage. Additional notes from respondents namely honest attitudes are one of the abstract attitudes that are not easy to observe directly and require not a short time to change and shape honesty. Songs can support the instilling of honest attitudes. However, it is not on its own sufficient and must be accompanied by other forms of teaching and media, including through learning by parents at home. 


\section{CONCLUSION}

Teachers and school principals in PAUD schools in Sleman Regency, Yogyakarta Special Province have a perception that the character values can be instilled early with songs as a learning media because songs can be effective media and they seem easily accepted by children.

Songs can be used as a media to instill character values and give effects to children if played and taught repeatedly. However, their effects on a children's behaviour seem not instantaneous and cannot be observed directly in a short period of time. Changes in children's behaviour require a long time, with the patient and consistent learning efforts.

Teachers and principals agree with the statement that the values of a religious character, tolerance, creativity, and social care, independence, curiosity, friendship, and peace-loving, being fond of reading, and environment caring, and social caring can be instilled more easily in early childhood through songs.

Songs can be a media to teach the values of discipline, independence, and curiosity. By being heard and taught the value of characters through songs, children can change and increase their courage in communicating and cause a sense of concern for the environment.

Besides, the value of honesty is one of the abstract attitudes requiring a relatively long time to change and shape. Songs can assist in the teaching and forming of honest attitudes. However, it is not adequate by itself and should be accompanied by other media and forms of teaching, including home learning by parents.

The choice of songs should also be appropriate for the age of the children and in harmony with the materials related to the values of the characters being studied in the teaching and learning process at school. The choice of song content for children should be based on very carefully considered and selected because, at an early age, children absorb information very quickly and store the information very well. In fact, it is very possible to instill so deeply the characters required for their adulthood. In addition, it is important to provide an explanation of the meaning of the theme contained in the song each time the children are to sing.

Furthermore, music and songs, to be a media for instilling good values, can also be a media for children to develop themselves in accordance with their abilities and interests. Children become more honest with the environment and themselves, with guidance from their teachers and parents. This is appropriate with the principles of postmodern teaching that views, knowledge, thoughts, and education are not objectives rooted evenly on humans with each other. Rather, they are subjective education which believes that the best teaching is by the environment that can direct and support the needs of each child and appreciate the differences of one another.

Learning with children's songs can support character education, but it is not enough by itself. Likewise, learning in schools is very helpful and influential in shaping the character of children, but it is incomplete and insufficient without learning in harmony with the family at home. The most important thing in shaping children's character is the synergy between learning at school and at home and is more effective when using the right media which is easily accepted, absorbed, and stored by the children as they are in using songs as a learning media.

With good synergy in early education, children are expected to have the provisions and strengths of good and strong character that is embedded in them. The character will become a provision in their life later to face the future in the postmodern era that is completely unpredictable as everything moves and develops very quickly.

\section{REFERENCES}

[1] K. Schwab, The fourth industrial revolution. New York: Crown Business, 2016. p. 38.

[2] Morrar, Rabeh, Husam Arman, and Saeed Mousa. "The fourth industrial revolution (Industry 4.0): A social innovation perspective." Technology Innovation Management Review 7.11 (2017): 1220. DOI: http://doi.org/10.22215/timreview/1114

[3] Ritzer, George, and Douglas J. Goodman. Teori Sosiologi: Dari Teori Sosiologi Klasik Sampai Perkembangan Mutakhir Teori Sosial Postmodern [Sociology Theory: From Classical Sociology Theory to the Latest Developments in Postmodern Social Theory]. Yogyakarta: Kreasi Wacana, 2008. p. 677.

[4] Ilham, Iromi. "Paradigma Postmodernisme; Solusi untuk Kehidupan Sosial? [Postmodernism paradigm; Solutions for Social Life?]" Jurnal Sosiologi USK (Media Pemikiran \& Aplikasi) 12.1 (2018): 1-23. URL:

http://www.jurnal.unsyiah.ac.id/JSU/article/view/1 1693

[5] Setiawan, Johan, and Ajat Sudrajat. Pemikiran Postmodernisme dan Pandangannya terhadap Ilmu Pengetahuan [Postmodernism's Thoughts and Views on Science]. Gadjah Mada University, 2018. pp. 25-46.

[6] Maksum, Ali. Pengantar Filsafat: Dari Masa Klasik Hingga Postmodern [Introduction to Philosophy: From Classical to Postmodern]. Yogyakarta: Ar-Ruz Media, 2014. pp. 305-306.

[7] Setiawan, Johan, and Ajat Sudrajat. Pemikiran Postmodernisme dan Pandangannya terhadap Ilmu Pengetahuan [Postmodernism's Thoughts and Views on Science]. Gadjah Mada University, 2018. p. 29 
[8] Setiawan, Johan, and Ajat Sudrajat. Pemikiran Postmodernisme dan Pandangannya terhadap Ilmu Pengetahuan [Postmodernism's Thoughts and Views on Science]. Gadjah Mada University, 2018. p. 27.

[9] Rahman, Fathur. "Tantangan Pendidikan Di Era Postmodernisme [Challenges of Education in The Postmodernism Era]." Al-Riwayah: Jurnal Kependidikan 9.2 (2017): 323-348. URL: http://e-jurnal.stainsorong.ac.id/index.php/AlRiwayah/article/view/136

[10] Suherman, Wawan S., and Endang Sulistyowati. "Analisis Terhadap Program Pendidikan Anak Usia Dini Pada Rencana Kerja Pemerintah Tahun 2009 [Analysis of Early Childhood Education Programs in the 2009 Government Work Plan]." Jurnal Cakrawala Pendidikan 1.1 (2009).

[11] A. N. Machfauzia, "The art of Gejog Lesung in modern times (A dedication for local wisdom)," unpublished.

[12] Fitria, Yunike Juniarti, and Tri Wahyuni Floriasti. "The Description of Song Composing of Terima Kasih Guruku as the Backing Song of MP4 Media in E-Learning Classroom." Imaji: Jurnal Seni dan Pendidikan Seni 16.2 (2018): 172-183.

[13] Kurnia, Nandy Intan, and Yunike Juniarti Fitria. "Pemanfaatan nursery rhymes sebagai media pendidikan karakter bagi anak usia dini [The use of nursery rhymes as a medium for character education for early childhood]." Jurnal Penelitian Ilmu Pendidikan 8.1 (2015).

[14] J. W. Creswell, Research design: qualitative, quantitative, and mixed methods approaches, Achmad Fawaid, Yogyakarta: Pustaka Pelajar, 2010 , p. 216.

[15] Nana, Syaodih Sukmadinata. Metode Penelitian Pendidikan [Educational Research Methods]. Bandung: PT Remaja Rosdakarya, 2007. p. 82.

[16] Çakici, Dilek. "Metacognitive Awareness and Critical Thinking Abilities of Pre-Service EFL Teachers." Journal of Education and Learning 7.5 (2018): 116-129. URL: https://eric.ed.gov/?id=EJ1185900

[17] Suharsimi, Arikunto. Prosedur Penelitian [Research Procedure]. Jakarta: Rineka Cipta, 2006. p. 116.

[18] Sugiyono. Statistika Untuk Penelitian [Statistics for Research]. Bandung: CV. Alfabeta, 2006. p. 71.
[19] J. W. Creswell, Research design: qualitative, quantitative, and mixed methods approaches, Achmad Fawaid, Yogyakarta: Pustaka Pelajar, 2010, pp. 217-218.

[20] Sugiyono. Statistika Untuk Penelitian [Statistics for Research]. Bandung: CV. Alfabeta, 2006. p. 134.

[21] Nur, Burhan, and Marzuki Gunawan. Statistik Terapan untuk Penelitian Ilmu-ilmu Sosial [Applied Statistics for Social Sciences Research]. Jakarta: PT Gramedia Pustaka Utama, 2004. p. 62. 